DIW BERLIN

Discussion Papers

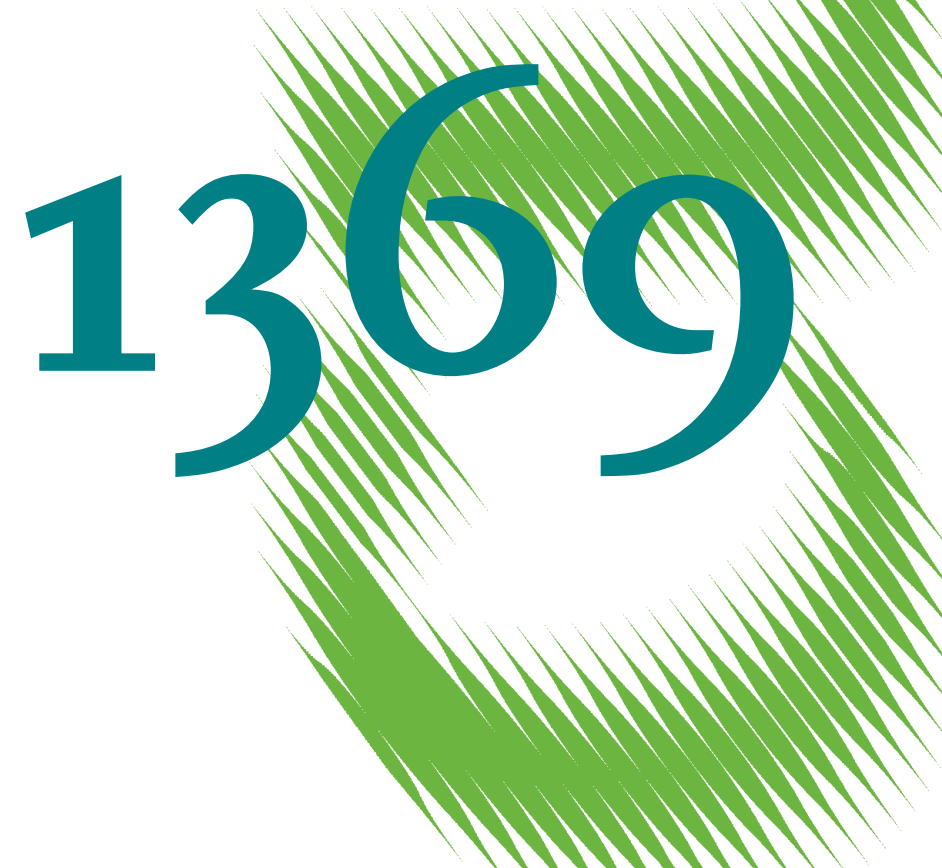

The Impact of Oil Revenues on the Iranian Economy and the Gulf States 
Opinions expressed in this paper are those of the author(s) and do not necessarily reflect views of the institute.

IMPRESSUM

(C) DIW Berlin, 2014

DIW Berlin

German Institute for Economic Research

Mohrenstr. 58

10117 Berlin

Tel. $+49(30) 89789-0$

Fax +49 (30) $89789-200$

http://www.diw.de

ISSN print edition $1433-0210$

ISSN electronic edition 1619-4535

Papers can be downloaded free of charge from the DIW Berlin website:

http://www.diw.de/discussionpapers

Discussion Papers of DIW Berlin are indexed in RePEc and SSRN:

http://ideas.repec.org/s/diw/diwwpp.html

http://www.ssrn.com/link/DIW-Berlin-German-Inst-Econ-Res.html 


\title{
The Impact of Oil Revenues on the Iranian Economy
}

\author{
and the Gulf States
}

\section{Christian Dreger}

\section{Teymur Rahmani ${ }^{1}$}

\begin{abstract}
In line with the neoclassical growth model a persistent stream of oil revenues might have a long lasting impact on GDP per capita in oil exporting countries through higher investment activities. This relationship is explored for Iran and the countries of the Gulf Cooperation Council (GCC) using (panel) cointegration techniques. The existence of cointegration between oil revenues, GDP and investment can be confirmed for all countries. While the cointegration vector is found to be unique for Iran, long run equations for GDP and investment per capita are distinguished for the Gulf countries. Both variables respond to deviations from the steady state, while oil income can be treated as weakly exogenous. The long run oil elasticities for the Gulf states exceed their Iranian counterparts. In addition, investment in Iran does not react to oil revenues in the long run. Hence, oil revenues may have been spent less wisely in Iran over the past decades.
\end{abstract}

Keywords: Oil exporting countries, oil revenues, panel cointegration

JEL classification: F43, O53, Q30, C33

\footnotetext{
${ }^{1}$ Dreger (corresponding author): DIW Berlin, Mohrenstr. 58, 10117 Berlin, Germany, cdreger@diw.de, Rahmani: University of Tehran, Iran, trahmani@ut.ac.ir. The authors would like to thank Kamiar Mohaddes from the University of Cambridge, UK for helpful discussions. Financial support from DAAD is gratefully acknowledged.
} 

The impact of oil prices on output is often examined from the perspective of industrial countries, i.e. net oil importers. The sharp increase in oil prices during the $1970 / 80$ s caused by the Arab oil embargo (1973/74) and the disruptions in the wake of the Iranian revolution (1979) led to stagflation, i.e. high inflation and low GDP growth in the advanced economies (Kilian, 2008a, b). In contrast, the subsequent oil price decrease in the 1980s and persistent low prices before the turn of the century acted as a stimulus program. During the economic boom in the period preceeding the financial crisis and the emergence of huge developing countries in Asia (China and India) in the world economy, oil prices reached new record levels (Aastveit, Bjørnland and Thorsrud, 2012). In the global recession, they fell again due to shrinking demand, but recovered fast thereafter (Figure 1).

-Figure 1 about here-

The effects are different from the perspective of oil exporting countries. An increase in oil prices leads to higher oil revenues. They may help to overcome one of the most important impediments for economic development; that is, low savings and subsequently low rates of investment. The revenues can transform the domestic economy without borrowing from abroad. The aim is to foster a less oil dependent industrial structure, given the fact that oil resources are finally exhaustible. Because of the rapid increasing labour force in many countries, a more robust development is required to create sufficient employment opportunities especially for the young. Increasing oil prices provide financial funds to address the challenges of the restructuring. Diversified industrial sectors can reduce the vulnerabilities against volatile global oil markets.

Since the stock of resources is limited, the impact of oil prices is often studied from a short run perspective. Oil price hikes lead to an accumulation of foreign exchange reserves in oil exporting countries. If the inflows are not sterilized, money supply will increase, with higher inflation pressure. According to Cashin, Céspedes and Sahay (2004) the improvement in the terms of trade will lead to an appreciation of the real exchange rate. This can worsen the development of production in the non-resources export oriented sectors, such as manufacturing (Sachs and 
Warner, 2001, Collier and Goderis, 2007). Long lasting effects are usually not expected, as the economy will re-adjust after the extra revenues diminish. Nonetheless, windfall gains can create incentives for rent-seeking and corruption behaviour of interest groups that can hamper the long term performance. Also, oil price swings appear to be highly persistent, given the nonstationarity of the series. Despite the fact that the resources are ultimately exhaustible, many oil exporting countries are able to produce for a rather long period, whether there is any progress in exploration and extraction technologies or not. After a century of oil exploration and production in Iran, the estimated reserve-to-production ratio suggests further 115 years of oil production (OPEC, 2013). Therefore, oil resources can be seen as permanent for a reasonable long time span, implying that the associated revenues might affect production in the steady state.

The main transmission channel through which oil income operates is via their effect on private and public capital accumulation. An increase in oil income generates funds not only to consume, but also to invest in public infrastructure. Private investment is often constrained by low domestic savings, and oil incomes are a tool to overcome this restriction. In fact, Basher and Stefano (2013) reported a long run relation between savings and investment for the Gulf Cooperation Council (GCC) countries. Higher oil incomes cause savings to increase and subsequently investment and capital accumulation, as the revenues are partially spend to modernize the domestic economy. The strength of the impact depends on the absorptive capacity of the economies. Higher imports of capital and intermediate goods may support the adoption of foreign technologies. Private consumption can be affected by government spending as well, for example through an increase of wages in the public sector to mitigate polictical and social pressure.

However, the positive effects cannot be taken as granted. Higher oil incomes can also act as an obstacle for long run growth, if they are accompanied by rent seeking. According to the resource curse hypothesis, economies rich in natural resources might experience lower growth than resource-poor economies. In seminal papers, Sachs and Warner $(1995,1999)$ reported a negative impact of the share of natural resources in overall exports on economic growth, even after controlling for other growth determinants. Cavalcanti, Mohaddes and Raissi (2012) and Mohaddes and Pesaran (2013) argued that the curse is related to the volatility of revenues and not to the endowment of resources per se. A resource curse could be driven by the institutional conditions that might foster voracity. Lane and Tornell (1996) emphasized that price hikes may trigger an increase in fiscal redistribution and lower growth when legal institutions 
are weak and powerful interest groups exist. According to Mehlum and Moene (2006) and Robinson, Torvik and Verdier (2006), the abundance of natural resouces will decrease overall income if institutions are grabber friendly.

Due to the opposite effects, the net impact of higher oil revenues on real GDP is mainly an empirical issue. Spillovers spreading from oil prices to the domestic economy have been confirmed by Zind (1999) for the GCC countries, as a positive correlation between oil revenues and output can be detected in the non-oil sectors. In contrast, Fasano-Filho and Wang (2001) did not find causality from public expenditures to non-oil GDP in the Gulf states. Hence, governments may reduce their spending without adverse effects on non-oil GDP growth. To some extent, such a result might be attributed to policies that have led to a less oil dependent industrial structure.

By applying a cointegration approach, Esfahani, Mohaddes and Pesaran (2014) detected long lasting positive effects of oil revenues on real per capita GDP for major oil exporting countries. Similar results are reported by Esfahani, Mohaddes and Pesaran (2013) for the Iranian economy, although inappropriate policies may have weakened the impact. A lack of appropriate institutions which act as shock absorbers in face of high volatile revenues might have become a drag on real output. In the SVAR analysis presented by Emami and Adibpour (2012), positive and negative oil shocks affect output growth in Iran in a concurrent way, but the short run effects appear to be asymmetric: While negative shocks adversely affect the economic performance, the impact of positive shocks is rather limited, probably due to the resource curse hypothesis.

This paper explores the relationship between GDP, investment and oil revenues for the Iranian economy and the GCC states. Iran serves as an example where the experience may be driven by the behaviour of conflicting interest groups (Hodler, 2006 and Bjorvatn and Selvik, 2008). Rent seeking in a highly fractionalized economy can lead to a waste of resources. See Rahmani and Valizadeh (2011) on the relevance of voracity for Iran. The lack of sufficient property rights may result in low private investment, and the imbalances in the distribution of political power can lead to distortions in the allocation of investment funds. In contrast, the GCC might be seen as an example for a more efficient use of revenues. As the macroeconomic develoment is largely driven by a common component, these countries are treated as an aggregate (Rafiq, 2011). 
The main findings of the paper are as follows: The existence of cointegration between oil revenues, GDP and investment can be confirmed for all countries. While the cointegration vector is unique for Iran, long run equations for GDP and investment per capita are distinguished for the Gulf countries. Both variables respond to deviations from the steady state, while oil income is weakly exogenous. The long run oil elasticities for the Gulf states exceed their Iranian counterparts. In addition, investment in Iran does not react to oil revenues in the long run. Eventually, oil revenues may have been spent less wisely in Iran over the past decades. The transmission via higher consumption expenditures might be more relevant.

The rest of the paper is organized in different sections. The next section (Section 2) provides a brief review of the economic development in Iran and the GCC countries over the past decades. The design of the empirical analysis is discussed in Section 3. The results are presented in Section 4 and Section 5 offers some policy conclusions.

\section{Oil income and output growth in Iran and the Gulf States}

Iran is among the most important countries regarding the endowment of natural resources. According to the OPEC Statistical Bulletin, the country owns about 10.6 percent (2012) of the global oil reserves, the second largest after Saudi Arabia (18 percent) ${ }^{2}$. Overall, the countries covered by the analysis represent 45 percent of the proven world oil reserves. In general, the oil sector is largely nationalised with regard to upstream activities, i.e. crude oil production. There is private involvement in downstream activities such as refining in some countries. Before the introduction of the recent sanctions by the US and the EU, oil accounted for 80 percent of the Iranian exports and up to 60 percent of fiscal revenues. Similar shares can be observed for the GCC countries. See Table 1 for some macroeconomic characteristics in different periods of the development.

Real oil revenues increased in Iran due to higher production over the 1965-71 period. The foundation of the OPEC in 1960 contributed as a stabilizer, after a long decline in real oil prices in previous years. While the share of the oil sector was about 20 percent of GDP, high output growth was achieved in a low inflationary environment. The 1970s (1972-79) were characterized by large increases in oil prices with unprecedented windfall gains for oil exporting countries. The Shah's regime revised initial development plans with ambitious targets and injected

\footnotetext{
${ }^{2}$ In addition, Iran is a major exporter of natural gas, with a share of 15 percent of global reserves, second largest after Russia.
} 
huge amounts of revenues into the economy. The fiscal expansion over a short period raised the dependency of Iran on oil income substantially (Mohaddes and Pesaran, 2013). Oil revenues increased by 14 percent on average, but with high fluctuations. For example, they rose by more than 30 percent per annum up to the mid of the 1970s. The share of the oil sector grew to 50 percent of GDP, but at the same time, output growth declined substantially. The boost of liquidity caused high inflation pressures, as production capacities did not expand at comparable rates. GDP growth was also depressed by a fast acceleration of imports due to an appreciation of the real exchange rate and losses of price competitiveness in the export oriented sectors. High oil production was largely seen as an indication for waste and corruption. Increasing sectoral imbalances and structual inefficencies contributed to the downfall of the Pahlevi regime.

-Table 1 about here-

The following years (1980-88) are characterized by the Islamic revolution, sanctions by the Western countries due to the hostage crisis in the US embassy and the war between Iran and Iraq. Economic growth almost stagnated, also because of inefficiencies traced to the nationalization of almost all industrial sectors and the destruction of infrastructures as an outcome of the war. Driven by the removal of sanctions, reconstruction efforts and structural reforms such as the privatization of formerly state owned enterprises in light industry sectors, the suspension of price controls and some progress in financial liberalization, the economy recovered later (1989-1996). GDP increased by 6 percent per year, also supported by a fast expansion of oil revenues. The gradual removal of price controls, the depreciation of the rial and expansionary fiscal and monetary policies led to high inflation rates, with a record height of 50 percent in 1995.

The economy became more stable in the following period (1997-04). Oil incomes increased by approximately 20 percent, while real output expanded at an annual rate of 5 percent. In contrast to the previous policy, oil incomes were only partially injected into the economy. Instead, a stabilization fund was established to mitigate the impact of huge swings in the oil price and the associated public expenditures. The fund was liquidated in the recent period (2005-12). The evolution was characterized by a strong increase in oil revenues, an expansionary fiscal and monetary stance with the aim to redistribute income to poorer households in smaller cit- 
ies and rural areas, and an unprecedented surge in imports. Although the injection of oil revenues in the economy increased, they seem to have supported the development to a less extent, probably due to rent-seeking, weak monetary and fiscal management and political instability. The decline of revenues in the last years is caused by the sanctions of Western countries on Iranian oil exports.

Similar to Iran, the Gulf states heavily rely on natural resources. Oil income to GDP ratios are even larger for these countries (Sturm, Strasky, Adolf and Peschel, 2008). Eroding prices in the 1980s depressed government spending and GDP. Despite almost stable and low oil prices, revenues recovered in the later period due to higher oil production. Compared to the Iranian experience, the evolution of oil revenues has been far less volatile, also because of the fact that shocks due to embargos, sanctions and other sources have been less pronounced. Windfall profits after the turn of the century boosted public expenditures and GDP growth, but only partially. The peg to the US Dollar exchange rate led to huge inflows of foreign reserves ${ }^{3}$. However, inflation did not increase markedly in most countries, as monetary policies were rather successful in sterilizing the impact on the domestic monetary base (Nakibullah, 2011). Revenues have been largely invested in sovereign wealth funds, where the US is the main destination for financial investment flows.

\section{Design of the analysis}

The long run effects of higher oil revenues are studied within the context of the neoclassical growth model, see Barro (2008) for an exposition. A key premise of this model is that technolgical progress is the ultimate source for sustainable long run growth. Esfahani, Mohaddes and Pesaran (2014) adapted the general framework to cover the conditions under which major oil exporters operate. Oil revenues are treated as exogenous. Oil prices are determined in international markets, and oil supply has been largely fixed by OPEC quotas. A share of the associated revenues is invested in each period, implying faster capital accumulation compared to the standard model.

If the growth rate of oil revenues remains below the combined growth rate of technical progress and population, oil revenues will not exert an impact on real income per capita in the

\footnotetext{
${ }^{3}$ The preference towards the US dollar could be explained by the fact that oil revenues are priced in US dollars. Furthermore, the peg shields foreign assets denominated in US dollars from exchange rate fluctuations.
} 
steady state. Since the revenues expand at a slower pace than real output, the share of oil income in output vanishes over time and the standard model becomes applicable. Hence, the level of capital and income per efficiency unit of labour are constant in the long run, implying that real per capita GDP and the level of technology are cointegrated. Provided that the latter can be approximated by a deterministic time trend, productivity should increase with limited fluctuations around this trend. However, if oil income growth exceeds the threshold, a permanent effect on per capita GDP is expected in the steady state. Due to the enormous increase in oil prices in recent decades (Table 1), the latter constellation is typical for most periods of the sample. This implies

$$
\ln \left(Y_{t} / L_{t}\right)-(1-\alpha) A_{t}-\alpha \ln \left(X_{t} / L_{t}\right) \sim I(0)
$$

a cointegration relationship between per capita income $(Y / L)$, per capita oil revenues $(X / L)$ and the index of technology $(A)$. Oil income will enter the long run output equation with a coefficient equal to the share of capital $(\alpha)$ in case that GDP is driven by a Cobb-Douglas production function. Since a long lasting impact of oil revenues will materialize through higher investment activities, an additional equation on the link between investment expenditures and oil revenues is also specified.

Stochastic trends in real per capita GDP, investment and oil revenues are detected by standard unit root tests, such as the GLS test of Elliott, Rothenberg and Stock (1996), among others. If the series are integrated, a long run equilibrium implies a cointegrating relationship between these variables. If cointegration exists, the level VAR could be equivalently written in a vector error correction form:

$$
\Delta \boldsymbol{Y}_{t}=\boldsymbol{\alpha} \boldsymbol{\beta}^{\prime} \boldsymbol{Y}_{t-1}+\sum_{j=1}^{p-1} \Gamma_{j} \Delta \boldsymbol{Y}_{t-j}+\boldsymbol{D}_{t}+\boldsymbol{\varepsilon}_{t}
$$

Where $\boldsymbol{Y}$ includes the variables under study, $\boldsymbol{\varepsilon}$ is the vector of errors sharing the white noise properties, $\boldsymbol{\alpha}$ denotes the matrix of feedback parameters, $\boldsymbol{B}$ the matrix of the cointegrating relations and $\boldsymbol{D}_{\mathrm{t}}$ includes the deterministic terms. In particular, an unrestricted constant and a linear time trend are included to allow for possible changes in the long run relationships over the sample period. The cointegration analysis is performed using the Johansen (1995) reduced rank approach. 
A modified strategy holds for the Gulf states. Because they are treated as an entity, panel integration and cointegration techniques will be applied. However, the conventional assumption of independent panel members is rejected, as oil price shocks hit the countries in a similar way. Thus, cross section dependencies are embedded via a common factor structure (Gengenbach, Palm and Urbain, 2006). Each series is decomposed into common and idiosyncratic factors, as suggested by Bai and $\mathrm{Ng}$ (2004). The former are extracted as principal components of the differenced series to rule out possible nonstationarities in the level representation. The number of principal components is determined by the usual information criteria (Bai and $\mathrm{Ng}$, 2002). Afterwards, the idiosyncratic components are constructed from an orthogonal projection of the differenced series on their common components. Finally, both the common and idiosyncratic components are re-cumulated to match the integration properties of the original series.

The integration and cointegration properties are investigated separately for the common and idiosyncratic elements. If a variable can be compressed into a single principal component, inference is conducted by standard time series tests. These tests are also valid if multiple principal components are allowed to enter a linear combination to obtain the common factor. The weights in the combination correspond to the eigenvalues of the principal components. As the defactored series are independent by construction, their properties are examined by standard panel tests, such as the Levin, Lin and Chu (2002) test for integration and the Pedroni (1999, 2004) tests for cointegration.

\section{$4 \quad$ Empirical results}

Data on GDP, investment, population, prices and exchange rates are taken from the IMF World Economic Outlook, the Central Bank of Iran and the Penn World Tables (Feenstra, Inklaar and Timmer, 2013). To obtain oil revenues, the oil price (West Texas Intermediate) is multiplied by exports in barrels, both reported in the OPEC Annual Statistical Bulletin. As oil exports are not available prior to the first oil crisis, they are inferred from oil production data, setting the export to production ratio to the average of the subsequent 5 years. Oil production before the first oil crisis is from the Statistical Review of World Energy published by British Petroleum. Nominal exchange rates to the US Dollar are applied to convert the oil revenues into domestic currencies. To construct variables in constant prices, GDP and investment are divided by the GDP deflator while oil revenues are deflated by the CPI. All series are expressed in log per capi- 
ta units and refer to the annual frequency. For Iran, the series cover the 1965-2012 period. For comparison, the post revolutionary period (1980-2012) is considered separately. The sample period is $1980-2012$ for the Gulf countries. No information for the GCC is available prior this point. It might be argued that the evidence might be less reliable due to the shorter observation period. However, inefficient estimates might be avoided due to the panel structure, as the time dimension is extended by the cross section. Bahrein is excluded from the GCC panel due to huge gaps in oil export data.

The first step of the analysis is to check the unit root properties of the variables involved. For the Gulf states the series are decomposed into common and idiosyncratic elements. Despite the fact that the information criteria do not converge, two principal components are selected for GDP and investment. They can capture slightly more than 60 percent of the overall variance of the respective variable. The share explained by the first two components is above 80 percent in case of oil revenues. The common factors are constructed via linear combinations of the principal components, where the weight of the first component is 0.65 for GDP and investment and 0.8 for oil revenues ${ }^{4}$.

-Table 2 about here-

All variables exhibit stochastic trends (Table 2). While the null hypothesis of a unit root cannot be violated for the variables measured in levels, it is soundly rejected for the first differences. For the Gulf states, this finding is traced to the common components. The idiosyncratic parts are stationary, i.e. they do not contain stochastic trends and could be safely excluded from the steady state. Thus, any cointegrating relationship between GDP, investment and oil revenues will emerge due to the presence of international trends. In principle, this result can weaken the analysis for the Gulf states. As the panel environment is lost, cointegration tests will be based on a rather moderate time span. However, it should be noted that the common components are likely more reliable than original variables, as idiosyncratic fluctuations have been filtered out by construction.

\footnotetext{
${ }^{4}$ All main results can be replicated, if the common factors refer only to the first principal component or arise as linear combinations of the first three principal components of the respective variables. Results are available from the authors upon request.
} 
Real per capita GDP, investment and oil revenues are cointegrated for Iran and the GCC countries. According to the trace test, the cointegration rank is different (Table 3). While the long run vector is unique for Iran, two independent relationships emerge for the Gulf states. Eventually they may be interpreted in terms of an output and investment equation. Both variables can be affected by oil revenues in the steady state.

The cointegration parameters are all well signed. For Iran, the elasticities of GDP to investment and oil revenues are 0.22 and 0.19 , respectively. While the investment parameter increased, oil revenues have become less important in the post-revolutionary era. Due to the evidence on the feedback mechanisms, investment and oil revenues are weakly exogenous to the cointegration relationship. In contrast the exogeneity hypothesis is rejected for GDP. Hence, the error correction term is significant and bears the correct sign in an equation governing output growth. Therefore, the cointegration relationship can be seen as an equation determining the steady state level of real per capita output.

-Tables 3 and 4 about here-

For the Gulf States, an output and investment equation can be distinguished. Oil revenues are fairly exogenous in both cases. Their long run impact on investment (0.46) exceeds the elasticity for output (0.29). Oil revenues appear to be more important for the GCC states compared to Iran. Besides the direct effect on GDP, an indirect effect can be expected via the investment channel. In contrast, no impact on investment could be detected for Iran. Hence the evidence suggests that oil revenues have been used less wisely for Iran, probably due to rent seeking and corruption problems.

\section{Conclusion}

In line with the neoclassical growth model a persistent stream of oil revenues might have a long lasting impact on GDP per capita in oil exporting countries through higher investment activities. This relationship is explored for Iran and the GCC states using (panel) cointegration techniques. The existence of cointegration between GDP, investment and oil revenues can be confirmed for all countries. While the cointegration vector is unique for Iran, equations for long run GDP and investment per capita can be distiinguished for the Gulf states. Both varia- 
bles react to deviations from the steady state, while oil revenues are weakly exogenous. The long run oil elasticities for the GCC countries exceed those for the Iranian economy. Hence, oil revenues may have been spend less wisely in Iran over the past decades. This finding is even more relevant for the post-revolutionary era, as the elasticity of oil revenues declined. Probably, a more gradual and planned infusion of oil revenues into the Iranian economy could be part of a prudent macroeconomic management after the economic sanctions. Similar to the Gulf states, the funds can be partially invested abroad for future use and act as a buffer against future global economic shocks. 


\section{References}

Aastveit KA, Bjørnland HC, Thorsrud LA (2012): What drives oil prices? Emerging versus developed economies, Working Paper 2012/11, Norges Bank.

Bai J, Ng S (2002): Determining the number of factors in approximate factor models, Econometrica 70, 191-221.

Bai J, Ng S (2004): A PANIC attack on unit roots and cointegration, Econometrica 72, 11271177.

Basher SA, Fachin S (2013): The long-run relationship between savings and investment in oilexporting developing countries: A case study of the Gulf Arab states, OPEC Economy Review $37,429-446$.

Bjorvatn K, Selvik K (2008): Destructive competition: Fractionalism and rent-seeking in Iran. World Development 36, 2314-2324.

Cashin P, Céspedes LF, Sahay R (2004): Commodity currencies and the real exchange rate, Journal of Development Economics 75, 239-268.

Cavalcanti TV de V, Mohaddes K, Raissi M (2012): Commodity price volatility and the sources of growth, IMF Working Paper 12/12.

Collier P, Godreis B (2007): Prospects for commodity exporters: Hunky dory or humpty dumpty? World Economy 8, 1-15.

Elliott G, Rothenberg T, Stock JH (1996): Efficient tests for an autoregressive unit root, Econometrica $64,813-836$.

Emami K, Adibpour M (2012): Oil income shocks and economic growth in Iran, Economic Modelling 29, 1774-1779.

Esfahani HS, Pesaran MH (2009): The Iranian economy in the twentieth century: A global perspective, Iranian Studies 42, 177-211.

Esfahani HS, Mohaddes K, Pesaran MH (2013): Oil exports and the Iranian economy, Quarterly Review of Economics and Finance 53, 221-237.

Esfahani HS, Mohaddes K, Pesaran MH (2014): An empirical growth model for major oil exporters, Journal of Applied Econometrics 29, 1-14. 
Fasano-Filho U, Wang Q (2001): Fiscal expenditure policy and non-oil economic growth: Evidence from GCC countries, IMF Working Paper 01/195.

Feenstra RC, Inklaar R, Timmer MP (2013): The next generation of the Penn World Table, http://www.ggdc.net/pwt.

Hodler R (2006): The curse of natural resources in fractionalized countries. European Economic Review 50, 1367-1386.

Johansen S (1995): Likelihood based inference in cointegrated vector autoregressive models, Oxford University Press, Oxford.

Kilian L (2008a): The economic effects of energy price shocks, Journal of the Economic Literature $46,871-909$.

Kilian L (2008b): Exogenous oil supply shocks: How big are they and how much do they matter for the US economy? Review of Economics and Statistics 90, 216-240.

Lane PR, Tornell A (1996): Power, growth, and the voracity effect. Journal of Economic Growth $1,213-241$.

Levin, Lin, Chu(2002): Unit root tests in panel data: Asymptotic and finite-sample properties, Journal of Econometrics 108, 1-24

Mehlum H, Moene K (2006). Institutions and Resourcs Curse. Economic Journal 116, 1-20.

Mohaddes K, Pesaran MH (2013): One hundred years of oil income and the Iranian economy: A curse or a blessing? Cambridge Working Papers in Economics 1302, University of Cambridge, UK.

Nakibullah A (2011): Monetary policy and performance of the oil-exporting Gulf Cooperation Councial countries, International Journal of Business and Economics 10, 139-157.

Pedroni P (1999): Critical values for cointegration tests in heterogeneous panels with multiple regressors, Oxford Bulletin of Economics and Statistics 61, 653-670.

Pedroni P (2004): Panel cointegration, asymptotic and finite sample properties of pooled time series tests with an application to the PPP hypothesis, Econometric Theory 20, 597-625.

Rahmani T, Valizadeh P (2011): An empirical examination of the voracity effect In Iran's economy, University of Tehran, Faculty of Economics. 
Rafiq MS (2011): The optimality of a gulf currency union. Commonalities and idiosyncrasies, Economic Modelling 28, 728-740.

Robinson JA, Torvik R, Verdier T (2006): Political foundations of the resource curse, Journal of Development Economics 79, 447-468.

Sachs JD, Warner AM (1995): Natural resource abundance and economic growth. NBER Working Paper 5398.

Sachs JD, Warner AM (1999): The big push, natural resource booms and growth, Journal of Development Economics 59, 43-76.

Sachs JD, Warner AM (2001). The curse of natural resources, European Economic Review 45, 827-838.

Sturm M, Strasky J, Adolf P, Peschel D (2008): The Gulf Cooperation Council countries. Economic structures, recent developments and role in the global economy, ECB Occasional Paper Series 92.

Zind RG (1999): Oil price movements and the Arabian Gulf economies: A sectoral analysis, Resources Policy 25, 59-67. 
Figure 1: Real oil prices

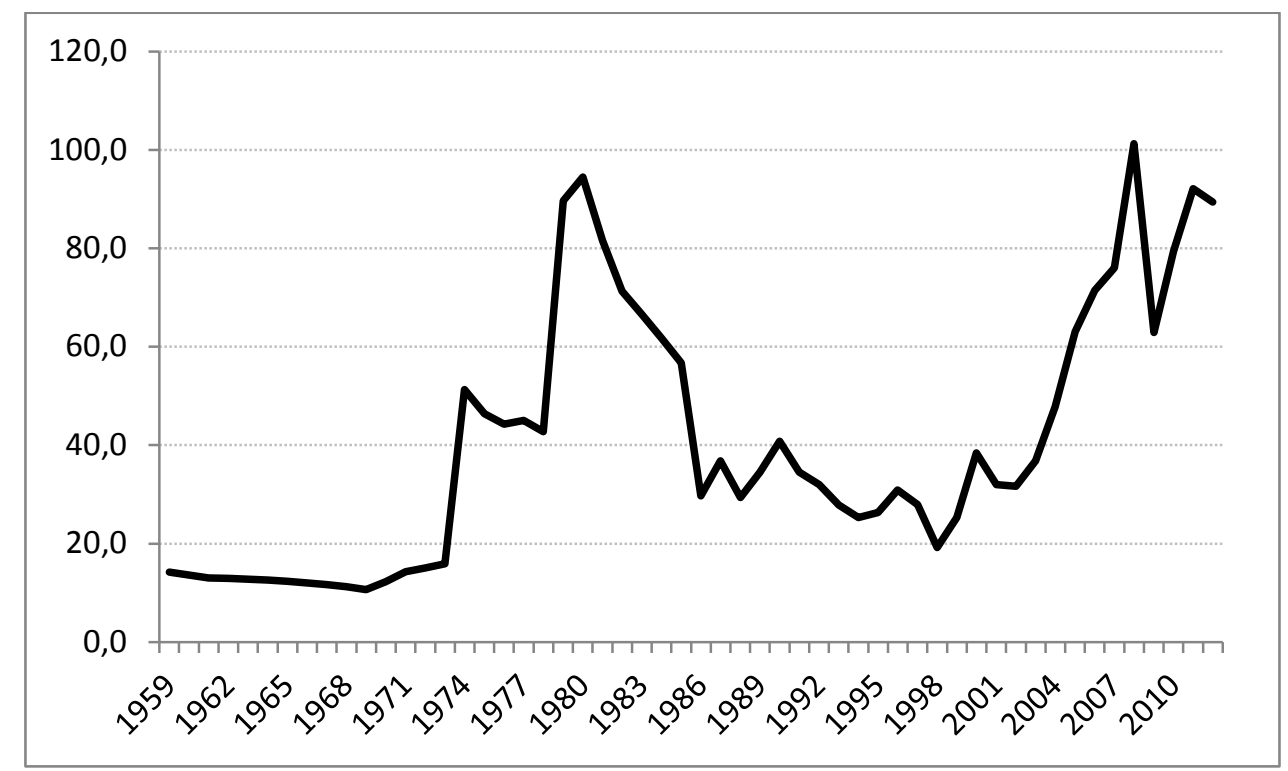

Note: IMF, International Financial Statistics. Oil price per barrel, West Texas Intermediate, deflated by the US CPI $(2009=100)$. 
Table 1: GDP growth, CPI inflation and change of oil revenues

\begin{tabular}{|l|c|c|c|c|c|c|}
\hline & \multicolumn{3}{|c|}{ Iran } & \multicolumn{3}{c|}{ Gulf Cooperation Countries } \\
\hline & GDP & Inflation & Oil & GDP & Inflation & Oil \\
\hline $1965-1971$ & 11.4 & 1.9 & 21.4 & & \\
\cline { 1 - 3 } $1972-1979$ & 3.7 & 13.4 & 14.2 & & 1.7 & -21.7 \\
\hline $1980-1988$ & 1.4 & 19.7 & -17.3 & -2.6 & 2.9 & 4.9 \\
\hline $1989-1996$ & 6.1 & 25.7 & 31.7 & 4.4 & 1.7 & 9.6 \\
\hline $1997-2004$ & 5.1 & 15.5 & 20.7 & 4.5 & 4.7 & 6.4 \\
\hline $2005-2012$ & 3.4 & 18.5 & -6.9 & 5.4 & & \\
\hline
\end{tabular}

Note: Subperiods according to phases in Iranian economy. Gulf Cooperation Countries include Kuwait, Oman, Qatar, Saudi Arabia and United Arabian Emirates. Bahrein excluded due to lack of oil export data. Oil revenues in for Iran in Rial, deflated by the CPI, for Gulf States in US Dollar, deflated by US-CPI. For Gulf inflation, country rates are weighted with GDP shares. 
Table 2: Unit root properties of the variables

\begin{tabular}{|l|c|c|c|l|}
\hline & \multicolumn{2}{|c|}{ Iran } & \multicolumn{2}{c|}{ Gulf States } \\
\hline & $1965-2012$ & $1980-2012$ & Common & Idiosyncratic \\
\hline GDP & $-1.951 \mid-4.588$ & $-2.581 \mid-3.469$ & $-1.239 \mid-3.629$ & $-2.729 \mid-7.640$ \\
\hline Investment & $-2.981 \mid-5.495$ & $-2.358 \mid-3.436$ & $-2.106 \mid-3.750$ & $-3.454 \mid-10.37$ \\
\hline Oil revenues & $-2.199 \mid-7.425$ & $-2.475 \mid-3.883$ & $-1.660 \mid-4.582$ & $-3.054 \mid-9.493$ \\
\hline
\end{tabular}

Note: All variables expressed in logs and real per capita terms. DF-GLS test according to Elliott, Rothenberg and Stock (1996) for Iranian series and Gulf common components, Levin, Lin and Chu (2002) test for idiosyncratic components. Left (right) entries refer to level (first difference) specification. Tests for the Iranian series and Gulf common components include a constant and trend in case of levels and a constant for the first differences. No deterministic terms employed the idiosyncratic parts. Critical values at 0.05 (0.01) level of significance are -2.89 (-3.48) for DF-GLS and -1.65 (-1.96) for Levin, Lin and Chu test. 
Table 3: Cointegration between the variables

\begin{tabular}{|l|c|c|c|}
\hline & \multicolumn{2}{|c|}{ Iran } & Gulf States \\
\hline Rank & $1965-2012$ & $1980-2012$ & $1980-2012$ \\
\hline$r \leq 0$ & 50.88 & 60.55 & 64.01 \\
\hline$r \leq 1$ & 15.25 & 18.61 & $29.43^{*}$ \\
\hline$r \leq 2$ & 3.44 & 5.97 & 4.97 \\
\hline
\end{tabular}

Note: All variables expressed in logs and real per capita terms. Entries refer to the trace test. Models for the Iranian and the Gulf economy include a constant and a linear time trend not restricted to the cointegrating relationship. For the Gulf states, cointegration refers to the common components. Lag specification according to the SBC criterion. Critical values at the $0.05(0.0)$ level for the trace test are 42.77 (48.87) for HO: $r \leq 0,25.73$ (30.67) for HO: $r \leq 1$, and 12.45 (16.22) for $\mathrm{HO}$ : $r \leq 2$. 
Table 4: Cointegration vectors and feedback mechanisms

A Iranian economy

\begin{tabular}{|l|c|c|}
\hline beta coefficents & $1965-2012$ & $1980-2012$ \\
\hline GDP & 1.000 & 1.000 \\
\hline Investment & $-0.215(0.083)$ & $-0.398(0.075)$ \\
\hline Oil revenues & $-0.185(0.037)$ & $-0.111(0.032)$ \\
\hline
\end{tabular}

\begin{tabular}{|l|c|c|}
\hline alpha coefficients & $1965-2012$ & $1980-2012$ \\
\hline$\Delta($ GDP $)$ & $-0.210(0.086)$ & $-0.162(0.085)$ \\
\hline$\Delta$ (Investment) & $0.036(0.315)$ & $0.787(0.428)$ \\
\hline$\Delta$ (Oil revenues) & $0.534(0.620)$ & $-0.493(0.868)$ \\
\hline
\end{tabular}

B Gulf States

\begin{tabular}{|l|c|c|}
\hline beta coefficients & First vector & Second vector \\
\hline GDP & 1.000 & - \\
\hline Investment & - & 1.000 \\
\hline Oil revenues & $-0.292(0.051)$ & $-0.455(0.116)$ \\
\hline
\end{tabular}

\begin{tabular}{|l|c|c|}
\hline alpha coefficients & First vector & Second vector \\
\hline$\Delta($ GDP $)$ & $-0.174(0.085)$ & $0.045(0.039)$ \\
\hline$\Delta$ (Investment) & $0.675(0.409)$ & $-0.491(0.186)$ \\
\hline$\Delta$ (Oil revenues) & $-0.176(0.785)$ & $0.699(0.357)$ \\
\hline
\end{tabular}

Note: All variables in logs and real per capita terms. Entries are long run parameters (beta coefficients) and feedback mechanisms in the different error correction equations (alpha coefficients). Standard errors in parantheses. 